\title{
Dynamics of collembolan communities inside the forested scree slope
}

\author{
Michal Rendošł, L’ubomír Kováč§, Andrej Mock§, Dana Miklisovál \\ ‡ Department of Ecology, University of Prešov, Prešov, Slovakia \\ § Department of Zoology, P. J. Šafárik University, Košice, Slovakia \\ | Institute of Parasitology, Slovak Academy of Sciences, Košice, Slovakia
}

Corresponding author: Michal Rendoš (michal.rendos@gmail.com)

Received: 28 Aug 2018| Published: 30 Aug 2018

Citation: Rendoš M, Kováč L, Mock A, Miklisová D (2018) Dynamics of collembolan communities inside the forested scree slope. ARPHA Conference Abstracts 1: e29368. https://doi.org/10.3897/aca.1.e29368

\section{Abstract}

The monthly dynamics of collembolan communities was studied over a year-long period in the depth profile of forested scree slope in the karst area of the Čierna hora Mts. (Western Carpathians, Slovakia). Collembola were sampled using non-baited subterranean traps consisted of a plastic cylinder with the small openings drilled around at 10 horizontal levels $(5-95 \mathrm{~cm})$, and a system of 10 plastic cups connected to each other by a helical rod and nuts. The plastic cylinder, after being buried in the slope profile, served as a protective casing for inserting the plastic cups filled with the preservative solution. The cups inside the cylinder were placed right under the openings on the cylinder perimeter, enabling to trap specimens in the particular depth. The temperature was measured continuously throughout the study at four-hour intervals using thermo-data loggers affixed to the wall of the plastic cups. During the year, the monthly temperature means on the surface ranged between $0.2^{\circ}$ $\mathrm{C}$ (January) to $16.6^{\circ} \mathrm{C}$ (August) while the monthly temperature means at the depth of $95 \mathrm{~cm}$ ranged between $3.5^{\circ} \mathrm{C}$ (April) to $15.2^{\circ} \mathrm{C}$ (September). Monthly temperature ranges varied from $5.0^{\circ} \mathrm{C}$ (February) to $12.5^{\circ} \mathrm{C}$ (October) on the surface and from $0.5^{\circ} \mathrm{C}$ (February, April) to $4.5^{\circ} \mathrm{C}$ (July) at $95 \mathrm{~cm}$. A total of 60 collembolan species were identified, among them 27 trogloxenes, 19 subtroglophiles, 12 eutroglophiles and 2 troglobionts. Fluctuations of the locomotory activity during the year were observed in all four categories of Collembola and at all depths. Redundancy analysis (RDA) revealed collembolan activity to be substantially affected by the thermal conditions fluctuating over the year. Most eutroglophiles and 
troglobionts, associated with deeper layers of the scree slope, preferred rather lower temperature ranges and were typical of the autumn months.

\section{Presenting author}

Michal Rendoš

\section{Presented at}

24th International Conference on Subterranean Biology, 20-24th August 2018, University of Aveiro, Portugal 